\title{
Retraction Note: Evaluation of English translation accuracy of green plant surface irrigation and food words based on image processing
}

\section{Ying Wang ${ }^{1}$}

Published online: 24 November 2021

C) Saudi Society for Geosciences 2021

\section{Retraction Note: Arabian Journal of Geosciences (2021) 14: 1440} https://doi.org/10.1007/s12517-021-07732-w

The Editor-in-Chief and the Publisher have retracted this article because the content of this article is nonsensical. The peer review process was not carried out in accordance with the Publisher's peer review policy. The author has not responded to correspondence regarding this retraction.

The original article can be found online at https://doi.org/10.1007/ s12517-021-07732-w.

Ying Wang

wangying89284@163.com

1 Wuhan Vocational College of Engineer and Software, Business School, Wuhan 430205, China 